\title{
COASTAL MIGRATORY CONNECTIONS OF HUMPBACK WHALES, MEGAPTERA NOVAEANGLIAE BOROWSKI, 1781, IN SOUTHERN CHILE.
}

\author{
CONEXIONES COSTERAS MIGRATORIAS DE BALLENAS JOROBADAS \\ MEGAPTERA NOVAEANGLIAE BOROWSKI, 1781, EN EL SUR DE CHILE.
}

Juan Capella ${ }^{1,2}$, Bárbara Galletti Vernazzani ${ }^{3}$, Jorge Gibbons ${ }^{5,6} \&$ Elsa Cabrera $^{3}$

\begin{abstract}
There is not published information on a comparative analysis about interchange of individual humpback whales between coastal areas of aggregation of the species along southern Chilean coast. Here we present a comparison of individually photo-identified humpback whales obtained off northwestern Chiloé Island, in Patagonian and Fuegian fjords and in the Strait of Magellan near Carlos III Island, to discover movements and interchange of individuals. Comparison of photographs resulted in conclusive matches of four individuals within the four study locations: two whales from Canal Wide (49 $55^{\prime} \mathrm{S}, 7^{\circ} 30^{\prime} \mathrm{W}$ ), one whale from Canal Cockburn (54 $\left.4^{\circ} 18^{\prime} \mathrm{S}, 72^{\circ} 15^{\prime} \mathrm{W}\right)$ and a mother-calf pair off northwestern Chiloé Island matched whales found near Carlos III. The minimum linear distance between these summering locations are approximately $80 \mathrm{~km}$ from Canal Cockburn to Carlos III, $540 \mathrm{~km}$ from Carlos III to Canal Wide, and $1300 \mathrm{~km}$ from Carlos III to northwestern Chiloé Island. The trip from Chiloé Island to Strait of Magellan during 38 days in the same summer season represented a minimum mean speed of transit of $34 \mathrm{~km} /$ day. This study provides the first evidence of direct connection of individual humpback whales along the coast of southern Chile.
\end{abstract}

Key words: humpback whales, Chile, cetaceans

\section{RESUMEN}

A lo largo de la costa del sur de Chile existen varias áreas de agregación de ballenas jorobadas durante el verano austral, pero no hay información publicada que analice el intercambio de ballenas entre ellas. En este trabajo se presenta una comparación de ballenas jorobadas identificadas individualmente

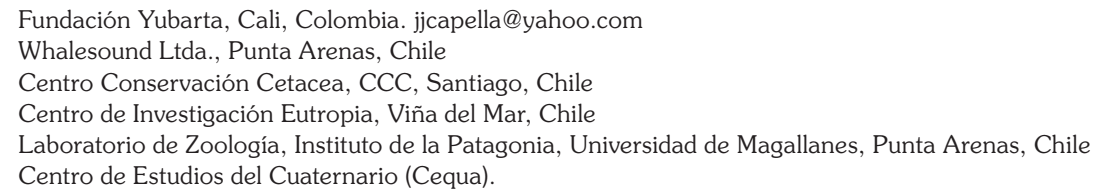


por fotografías obtenidas en el noroeste de la isla de Chiloé, en los fiordos Patagónicos y Fueguinos y cerca de la isla Carlos III en el estrecho de Magallanes, con el fin de descubrir el movimiento e intercambio entre estas áreas. La comparación resultó en el hallazgo de cuatro ballenas comunes entre el estrecho de Magallanes y los demás sectores: dos ballenas del canal Wide (4955'S, 74³0'W), una del canal Cockburn (54 $\left.4^{\circ} 18^{\prime} \mathrm{S}, 7^{\circ} 15^{\prime} \mathrm{W}\right)$ y una madre con su cría del noroeste de la isla de Chiloé también se encontraron en los alrededores de la isla Carlos III. La distancia lineal mínima entre estas localidades de verano es aproximadamente $80 \mathrm{~km}$ desde el canal Cockburn a Carlos III, $540 \mathrm{~km}$ desde Carlos III al canal Wide, y $1300 \mathrm{~km}$ desde Carlos III al noroeste de la isla de Chiloé. El viaje desde el noroeste de la isla de Chiloé hacia el estrecho de Magallanes en 38 días durante el mismo verano representa una velocidad mínima promedio de tránsito de $34 \mathrm{~km} /$ día. Este estudio proporciona la primera evidencia de una conexión directa de individuos de ballena jorobada a lo largo de la costa del sur de Chile.

Palabras clave: ballenas jorobadas, Chile, cetáceos.

\section{INTRODUCTION}

Humpback whales, Megaptera novaeangliae (Borowski, 1781), inhabit all major ocean basins and undertake long-distance seasonal migration between productive high-latitude areas where whales feed in the summer and fall, and low-latitude tropical waters where mating and calving occur during winter and spring (Mackintosh 1965, Clapham \& Mead 1999). Photographic identification of individual humpback whales, among others methods, has confirmed migratory destinations and connections all over the world (Stone et al. 1990, Darling \& Cerchio 1993, Darling et al. 1996, Stevick et al. 1998, Stevick et al. 2003).

In the eastern South Pacific, breeding grounds of humpback whales are grouped into stock $G$, which includes whales breeding during the austral winter along the coasts from northern Perú to Panamá and Costa Rica (Florez-González et al. 1998, Acevedo et al. 2007, Rasmussen et al. 2007). The main summer feeding ground for the southeastern Pacific humpback whale stock extends along the western coast of the Antarctic Peninsula (Omura 1953, Mackintosh 1942, Stone et al. 1990, Stevick et al. 2004), south to the Antarctic Convergence. A secondary and recently discovered feeding ground is found in the cold inshore waters of western South America, in the southern Patagonian fjords and the Strait of Magellan (SM) (Gibbons et al. 1998, Gibbons et al. 2003) with the most significant concentrations around Carlos III Island from summer to autumn (Gibbons et al. 2003, Gibbons et al.2004).
Based upon photographic identification effort and sighting records, another three areas of summer aggregation of humpback whales in feeding behavior have been reported: one in central Chile, around Chañaral Island and Choros/Damas (Capella et al. 1999, Moraga et al. 2008') and two others in southern Chile, in the northwestern Chiloé Island (Galletti Vernazzani et al. 2006², 20083) and the Golfo Corcovado (Hucke-Gaete et al. 20064). However, to date there is not published information on a comparative updated analysis about interchange of individuals between these areas.

Here we present results on comparisons from a collection of photo-identification catalogues of individual humpback whale curated by different organizations and obtained off northwestern Chiloé Island (Centro Conservación Cetacea), in Patagonian

Moraga, R., J. Capella, M.J. Pérez, Y. Vilina \& J. Gibbons. 2008. Diversidad de mamíferos marinos en las reservas marinas islas Choros-Damas e isla Chañaral, Chile: 20 años de registros. Resúmenes XIII Reunión de Trabajo de Especialistas en Mamíferos Acuáticos de América del Sur - $7^{\circ}$ Congreso SOLAMAC, 13-17 Octubre, Montevideo, Uruguay.

2 Galletti Vernazzani, B., C. Carlson, E. Cabrera and R.L. Brownell Jr. 2006. Blue, sei and humpback whale sightings during 2006 field season in northwestern Isla de Chiloe, Chile. Paper SC/58/SH17 presented to the International Whaling Commission Scientific Committee, St. Kitts and Nevis, May 2006 (unpublished). 6pp.

3 Galletti Vernazzani, B., C. A. Carlson, E. Cabrera, J. Capella \& R.L. Brownell, Jr. 2008. Recent humpback whale sightings off Isla de Chiloe, 2006-2008. Paper SC/60/SH26 presented to the Scientific Committee of the International Whaling Commission, June 2008, Santiago, Chile

4 Hucke-Gaete, R., J. P. Torres-Flórez, F. A. Viddi, S. Cuellar, Y. Montecinos \& J. Ruiz 2006. A new humpback whale (Megaptera novaeangliae) feeding ground in northern Patagonia, Chile: extending summer foraging ranges. Report SC/58/SH10 to the Scientific Committee of the International Whaling Commission. St Kitts and Nevis. 16 - 20 June. 
and Fuegian fjords and in the Strait of Magellan (Whalesound Ltda./Fundación Yubarta), with the aim to discover possible movements and interchange of individuals along the Chilean coast.

\section{MATERIALS AND METHODS}

\section{Study locations, effort and data collection}

Four main summering aggregations of humpback whales in southern Chile were analyzed along the Chilean coast:

a) The central sector of the Strait of Mage-

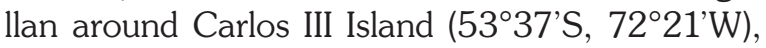
including Whale Sound, Tortuoso Passage, and Jerónimo and Barbara Channels. The study area covers approximately $1,150 \mathrm{~km}^{2}$ of marine channels, waters up to $600 \mathrm{~m}$ in depth, strong current flows and an average surface water temperature ranging between $6^{\circ} \mathrm{C}$ and $8^{\circ} \mathrm{C}$. Photographic data of individual whales were obtained from dedicated field work conducted on small vessels from 1999 to 2008 undertaken during 350 vessel-days between January and April-May of each year.

b) The Patagonian fjords along inner waters from south of the Penas Gulf ( $47^{\circ} 40^{\prime}$ 'S) to the northwestern of the Strait of Magellan (52 40 'S).The area include the main channels that connect this area with the Pacific Ocean (Messier, Wide, Trinidad, Sarmiento and Concepción) and secondary channels and fjords. This zone is characterized by cold waters with low salinity due to the high rainfall, fresh water influx from rivers and glacial melting. Photographic data of individual whales were obtained in 13 cruise surveys carried out monthly on medium size vessels between February 1997 to May 1998, during 77 days of navigation.

c) The Fuegian fjords located to the south of the Strait of Magellan, between Paso Shag (Bárbara Channel) (534' 5 ) and the east of Navarino Island (55 $\left.10^{\circ} \mathrm{S}\right)$. These are similar to the Patagonian fjords in environmental heterogeneity and varied geography, although glacial influence from the Darwin mountains is less important than from the Southern Ice Fields. Photographic data of individual whales were obtained during six marine trips made in December 1999, April, August, October and November 2000 and February 2001, for a total of 63 days. These surveys were made using vessels $14-16 \mathrm{~m}$ in length along a predetermined $490 \mathrm{~km}$ track d) The open waters off northwestern Chiloé Island between $41^{\circ} 45^{\prime} \mathrm{S}$ and $42^{\circ} 05^{\prime} \mathrm{S}$ and within $22 \mathrm{~km}$ off the coastline. Photographic data of individual whales were collected during 46 days of marine surveys on board artisan fishing vessel conducted between February and April, 2006 to 2008. The area covers approximately $1,000 \mathrm{~km}^{2}$ with water depth up to $150 \mathrm{~m}$ and in-situ sea surface temperature ranging from $13^{\circ} \mathrm{C}$ to $21^{\circ} \mathrm{C}$ during the study period.

\section{Identification and matching}

Humpback whales were individually identified from photographs of the unique patterns of ventral fluke pigmentation and the natural markings and permanent scars on the associated dorsal fins (Katona \& Whitehead 1981). Matches of humpback whales were found by comparing the collection of individuals identified among different areas. The total individuals catalogued includes 102 adult humpback whales in the Strait of Magellan (Capella and Gibbons unpublished catalog), 2 individuals in Patagonian fjords (Capella and Gibbons unpublished catalog), 1 individual in Fuegian fjords (Capella and Gibbons unpublished catalog) and 23 individuals in northwestern Chiloé Island (CCC unpublished catalog). The sex of whales was identified from skin biopsies obtained in Carlos III Island by amplification via the PCR and subsequent Taq I digestion of a homologous region of the $\mathrm{X}$ and $\mathrm{Y}$ chromosomes (details of the method is described in Sabaj et al. $2004^{5}$ and Capella et al. in press).

\section{RESULTS}

Comparison of photographs resulted in conclusive matches of four individuals within four of the five study locations as is shown in the accompanying photographs (Fig. 1). One adult whale (EMa-015 from the Strait of Magellan) was documented in Wide Channel (49 $55^{\prime}$ S, $\left.74^{\circ} 30^{\prime} \mathrm{W}\right)$ on 9 February 1997 and near Carlos III on 22 February and 29 April 1999. One of two adult whales (EMa-004) was identified in Canal Wide (49 57’S, 74²7’W)

\footnotetext{
Sabaj, V., Y. Vilina, S. Guerrero, J. Capella, J. Gibbons \& C. Valladares 2004. Genetic structure of the recently discovered feeding ground of Humpback whales at Straits of Magellan, Chile. Paper SC/56/SH19 submitted to the Scientific Committee of the International Whaling Commission, Sorrento, June 2004. 9pp.
} 
on 1 March 1997 and near Carlos III several times on 1999, 2000, 2002 to 2005, 2007 and 2008. One adult whale (EMa-025) was photographed on 25 February 2001 in Canal Cockburn (54 18'S, $\left.72^{\circ} 15^{\prime} \mathrm{W}\right)$ and near Carlos III Island on 11 February 2001, 13 March 2007 and 27 April 2008. Finally, a mother-calf pair (EMa-058) was photo-identified off northwestern Chiloé Island on 8 February 2008 and near Carlos III on 18 and 23 March 2008. The mother was also sighted in Strait of Magellan several days on February 2005, January 2006, February and March 2007 but never had been observed with a calf before 2008 .

The minimum lineal distance between these summering locations ranges from as short as $80 \mathrm{~km}$ for Canal Cockburn to Carlos III, $540 \mathrm{~km}$ approximately for the Carlos III to Wide Channel, and as long as $1300 \mathrm{~km}$ approximately for Carlos III to northwestern Chiloé Island. The trip from Chiloé to SM during 38 days in the same summer season represented a minimum mean speed of transit of $34 \mathrm{~km} /$ day.

\section{DISCUSSIONS AND CONCLUSIONS}

Comparison of individually identified humpback whales presented in this note covers a significant area of the main known range of aggregation or presence of the species in their summering ground along Chile: northwestern Chiloé Island, Patagonian and Fuegian fjords and the Strait of Magellan. Although there is limited data on photo identification in areas north and south of Strait of Magellan, this study provides the first evidence of exchange of humpback whales along the coast of southern Chile. The evidence of exchange between northern Patagonian fjords and the Strait of Magellan in different years, the direct connection of a mother and calf between northwestern Chiloé Island and Strait of Magellan in summer 2008, and the re-sighting of one adult between Strait of Magellan and Fuegian fjords in summer 2001 is a valuable information to understand migratory connections of humpback whales.

Available information indicates that humpback whales can stay until five months in the Strait of Magellan (Gibbons et al. 2003, Acevedo 2006

\footnotetext{
Acevedo, J.A. 2006. Distribución, filopatría, residencia e identidad poblacional de las ballenas jorobadas, Megaptera novaeangliae, que se alimentan en las aguas del Estrecho de Magallanes, Chile. Tesis de Maestría, Facultad de Ciencias, Universidad de Magallanes, Punta Arenas, Chile. 119 pp.
}

Capella et al. in press ${ }^{7}$ ) while in the area off Chiloé Island it is known that one whale was resident for a minimum of 20 days (Galletti Vernazzani et al., 2008). No data on residency exist until date for northern Patagonian and Fuegian fjords. In addition, the Strait of Magellan has been documented as a summer feeding ground for humpback whales (Gibbons et al. 2003, Acevedo 2006), while in the other three areas, feeding activities have also been recorded (pers. obs of the authors).

Although our data suggest a migratory connection for humpback whales, there are not recent sightings from Patagonian and Fuegian fjords to strengthen connection hypothesis. Additional data will be needed to resolve if humpback whales only travel through the fjords or if they stay there during summer as occurs near Carlos III Island waters (Gibbons et al. 2003, Acevedo et al. 2006). Further studies in southern Chile, particularly oriented to photoidentification, are essential to better understand migratory movements of humpback whales and propose a suitably migratory coastal route along southern Chile in a feeding ground that may extend from $54^{\circ} \mathrm{S}$ to at least $41^{\circ} \mathrm{S}$.

An alternative migratory connection for Chiloé's Island humpback whales is the western Antarctic Peninsula. Photographs of flukes and dorsal fins from eight individual humpback whales identified between 2004 to 2007 off northwestern Chiloé Island were provided by CCC to the Antarctic Humpback Whale Catalogue (AHWC, curated by Allied Whale, College of the Atlantic, Maine, USA). No matches have been found between individuals off northwestern Chiloé Island $(n=8)$ and the 3023 individuals catalogued in the AHWC from areas including the Antarctic Peninsula ( $\mathrm{n}=891)$, Antartic areas II to VI ( $n=380)$, Gabon $(n=78)$, Ghana $(n=1)$, South Africa ( $n=1)$, St. Helena $(n=2)$, Brazil $(n=830)$, Peru ( $n=2)$, Chile ( $n=76)$, Ecuador/Colombia/Costa Rica $(n=479)$, American Samoa $(n=44)$, Tahiti $(n=1)$, New Zealand $(n=1)$, E. Australia $(n=7)$ and Western Australia ( $\mathrm{n}=308$ ) (Allen et al. 20078).

\footnotetext{
Capella, J., J. Gibbons, L. Flórez-González, M. Llano, C. Valladares, V. Sabaj \& Y. Vilina En prensa. Migratory round-trip of individually identified humpback whales of the Strait of Magellan: clues on transit times and phylopatry to destinations. Revista Chilena de Historia Natural xxxx.

8 Allen, J.M., Carlson, C., Holm, B. and Stevick, P. 2007. Interim report: IWC Research Contract 16, Antarctic Humpback Whale Catalogue. Paper SC/59/SH17 presented to the International Whaling Commission Scientific Committee, Alaska, USA, May 2007 (unpublished). 7pp.
} 
Comparisons between northwestern Chiloé Island and the Antarctic Peninsula further strengthen the genetic and phenotypic evidence that suggest there is not migratory connection between Strait of Magellan and Western Antarctic Peninsula (Sabaj et al. 2004, Acevedo et al. 2007). It appears that humpback whales found near shore in southern Chile have separated migratory destinations.

\section{ACKNOWLEDGMENTS}

Authors wish to thank to WhaleSound Ltda., Fundación Yubarta, Universidad de Magallanes, Ministerio de Bienes Nacionales, Instituto de Fomento Pesquero (IFOP), Direction of Maritime Territory (DIRECTEMAR), Rufford Small Grants Foundation and Global Ocean for support. The work of JG and $\mathrm{JC}$ in Chile was partially supported by grants from the "Acción Integrada Universidad Complutense de Madrid - Universidad de Magallanes". We are grateful to Dr. Carole Carlson and Dr. Robert Brownell for the support to CCC projects in Chiloé Island and to Luis Bertea, Derek Corcoran, Daniela Droguett, José Zamorano for fieldwork assistance in the Strait of Magellan.

\section{LITERATURE CITED}

Acevedo, J.A., A. Aguayo-Lobo \& L.A. Pastene 2006. Filopatría de la ballena jorobada (Megaptera novaeangliae Borowski, 1781), al área de alimentación del Estrecho de Magallanes. Revista de Biología Marina y Oceanografía 41: 11-19.

Acevedo J., K. Rasmussen, F. Félix, C. Castro, M. Llano, E. Secchi, M.T. Saborío, A.

Aguayo-Lobo, B. Haase, M. Scheidat, L. Dalla-Rosa, C. Olavarría, P. Forestell, P. Acuña, G. Kaufman \& L. Pastene 2007. Migratory destinations of humpback whales from the Magellan Strait feeding ground, southeast pacific. Marine Mammal Science 23(2):453-463.

Capella, J., Y. Vilina \& J. Gibbons 1999. Observación de cetáceos en Isla Chañaral y nuevos registros para el área de la Reserva Nacional Pingüino de Humboldt, norte de Chile. Estudios Oceanológicos 18: 57-64.

Clapham, P.J. \& J.G. Mead 1999. Megaptera novaeangliae. Mammalian Species N 604: 1-9.
Darling, J.D., J. Calambokidis, K. Balcomb, P. Bloedel, K. Flynn, A. Moshizuki, K. Mori, F. Sato, H. Suganuma \& M. Yamaguchi 1996. Movement of a humpback whale (Megapetra novaeangliae) from Japan to British Columbia and return. Marine Mammal Science 12: 281-287.

Darling, J.D. \& S. Cerchio 1993. Movement of humpback whale (Megaptera novaeangliae) between Japan and Hawaii. Marine Mammal Science 9: 84-89.

Flórez-González, L., J. Capella, B. Hasse, G.A. Bravo, F. Félix \& T. Gerrodette 1998. Changes in winter destinations and the northernmost record of southeastern Pacific humpback whales. Marine Mammal Science 14: 189-196.

Gibbons, J., J. Capella, R. Matus \& L. Guzmán 1998. Presence of humpback whales, Megaptera novaeangliae (Balaenopteridae), in the Chilean Patagonian channels. Anales Instituto Patagonia, Serie Cs. Nat. (Chile) 26: 69-75.

Gibbons, J., J. Capella \& C. Valladares 2003. Rediscovery of a humpback whale, Megaptera novaeangliae, summering ground in the Strait of Magellan, Chile. Journal of Cetacean Research and Management 5: 203-208.

Gibbons, J., J. Capella \& Y. Vilina 2004. Ventral fluke pigmentation of humpback whale, Megaptera novaeangliae, population at the Francisco Coloane marine park, Straits of Magellan, Chile. Anales Instituto Patagonia, Serie Cs. Nat. (Chile), 32:63-67.

Katona, S. \& H. Whaitehead 1981. Identifying humpback whales using their natural markings. Polar Record 20: 439-444.

Mackintosh, N.A. 1942. The Southern Stocks of Whalebone Whales. Discovery Reports 22: 197-300.

Mackintosh, N.A. 1965. The stocks of whales. The Buckland Foundation, Coward \& Gerrish Ltd., Larkhall, Bath. United Kingdom. 232 pp.

Omura, H. 1953. Biological study on humpback whales in the Antarctic Whaling areas IV and V. Scientific Report of Whales Research Institute 8: 81-102.

Rasmussen, K., D. M. Palacios, J. Calambokidis, M.T. Saborío, L. Dalla Rosa, E. R. Secchi, G. H. Steiger, J. M. Allen \& G. S. Stone 2007. 
Southern Hemisphere humpback whales wintering off Central America: insights from water temperature into the longest mammalian migration. Biology Letters 3: 302-305.

Stevick Peter T., A. Aguayo, J. Allen, I.C. Avila, J. Capella, C. Castro, K. Chater, M. H. Engel, F. Felix, L. Flórez-González, A. Freitas, B. Haase, M. Llano, L. Lodi, E. Munoz, C. Olavarría, E. Secchi, M. Scheidat \& S. Siciliano 2004. A note on the migrations of individually identified humpback whales between the Antarctic Peninsula and South America. Journal of Cetacean Research and Management 6: 109-113.
Stevick, P.T., J. Allen, P.J. Clapham, S.K. Katona, F. Larsen, J. Lien, D.K.Mattila, P.J. Palsbøll, J. Robbins, J. Sigurjansson, T.D. Smith \& P.S. Hammond 2003. Segregation of migration by feeding ground origin in North Atlantic humpback whales (Megaptera novaeangliae). Journal of Zoology 259: 231-237.

Stevick, P.T., N. Oien \& D.K. Mattila 1998. Migration of a humpback whale (Megaptera novaeangliae) between Norway and the West Indies. Marine Mammal Science 14: 162-166.

Stone, G.S., L. Flórez González \& S. Katona 1990. Whale migration record. Nature 346 (6286): 705. 